\title{
Peningkatan Keterampilan Sosial melalui Kegiatan Tari Saman
}

\author{
Mulya Sari $^{1}{ }^{凶}$, Elindra Yetti $^{2}$, Asep Supena ${ }^{3}$ \\ Pendidikan Anak Usia Dini, Universitas Negeri Jakarta \\ DOI: $\underline{10.31004 / \text { obsesi.v4i1.240 }}$
}

\begin{abstract}
Abstrak
Tujuan dari penelitian ini adalah untuk mengetahui proses implementasi bermain tari saman untuk meningkatkan keterampilan sosial anak kelas Dua SD Negeri Satu Rikit Gaib. Penelitian ini menggunakan penelitian tindakan model Kemmis dan Mc Taggart. Subjek pada penelitian ini adalah anak laki-laki kelas Dua SD Satu Rikit Gaib sejumlah 11 anak. Penelitian ini dilakukan sebanyak Dua siklus, siklus pertama sejumlah delapan kali pertemuan dan siklus yang keDua sebanyak empat kali pertemuan. Analisis data pada penelitian ini menggunakan kualitatif dan kuantitatif. Analisis kuantitatif menggunakan statistik deskriptif untuk membandingkan hasil pada siklus pertama dan siklus keDua. Analisis data kualitatif dengan cara menganalisis data dari hasilcatatan lapangan dan wawancara selama penelitian dengan langkah-langkah reduksi data, displaydata dan verifikasi data. Hasil penelitian menunjukkan bahwa keterampilan sosial melalaui kegiatan tari saman meningkat dengan baik. Hal ini terlihat dari keberhasilan setiap siklus penelitian.
\end{abstract}

Kata kunci : keterampilan sosial; tari saman, anak usia dini

\begin{abstract}
The objective of this research was to determine the process of implementation of Saman dance in increasing child social skills at Primary School 1 Rikit Gaib. This research is an action research which refers to the model of clasroom action research by Kemmis and Mc. Taggart.The subject of this research aresecond grade male elementary school students, there are 11 children. This research consist by two cycles, first cycle consist of eight times in actions and the second cycle consists of four times in actions.The analysis of the data used qualitative and quantitative approaches. The analysis of quantitative data used descriptive statistics that compare the results obtained from the first cycle and the second cycle. While the analysis of qualitative data used analyzing daa from the field notes and interviews during the research by steps of data reduction, data display and data verification. The results showed that social skills through saman dance activities improved well. This can be seen from the success of each research cycle.
\end{abstract}

Keywords: social skills; saman dance; early childhood

Copyright (c) 2019 Mulya Sari, Elindra Yetti, Asep Supena

$\square$ Corresponding author:

Email Address : mulyasariariga@gmail.com (Gayo Lues, Aceh)

Received 20 July 2019, Accepted 28 August 2019, Published 30 August 2019 


\section{PENDAHULUAN}

Pendidikan pada masa usia dini merupakan wahana pendidikan yang sangat fundamental dalam memberikan kerangka dasar dalam terbentuknya dan berkembangnya dasar-dasar pengetahuan, sikap dan keterampilan pada anak. Keberhasilan suatu proses pendidikan yang dimulai sejak usia dini akan menjadi dasar untuk menyiapkan sumber daya manusia yang berkualitas.

Salah Satu aspek perkembangan dalam pendidikan anak usia dini adalah keterampilan sosial yang merupakan salah Satu kemampuan yang harus dimiliki sejak dini agar individu tersebut mampu mengahadapi problema hidup sebagai makhluk sosial yang selalu berintraksi secara terus-menerus, dan membutuhkan kehadiran dan bantuan orang lain (Megawangi, Dona, Yuslinta \& Diana, 2010). Penelitian terdahulu menjelaskan bahwa perkembangan keterampilan sosial anak berpengaruh pada prilaku menyontek atau melakukan kecurangan, karena kurangnya pemahaman tentang pentingnya menjaga hubungan sosial yang positif (Connor \& Evans, 2019). Kemudian peran kemampuan sosial dalam kesulitan bersosialisasi dan berintraksi dapat meningkatkan gejala kecemasan sosial pada anak, seperti hubungan pertemanan yang kurang baik ( Pickard, Happe, \& Mandy, 2018).

Penelitian selanjutnya Kızbes Meral Kılıç Mengungkapkan bahwa terdapat pengaruh positif program pelatihan keterampilan sosial terhadap keterampilan sosial anak, sedangkan anak yang sering mengalami temperamen dapat menyebabkan keterampilan sosial yang rendah (Kızbes Meral Kılıc, 2017). Kemudian Takahashi, Okada, Hoshino, \& Anme, menjelaskan bahwa praktik pengasuhan orang tua memberikan kontribusi yang berbeda untuk pengembangan keterampilan sosial anak yang dilihat dari tiga dimensi keterampilan sosial, yaitu Kerjasama, Kontrol diri,dan perilaku (Takahashi, Okada, Hoshino, \& Anme, 2015). Maksud dari tiga dimensi tersebut adalah membangun kerjasama yang baik dapat dilakukan dengan memberikan pemahaman kognitif dan emosional pada anak, kemudian Kontrol diri dapat ditingkatkan dengan memberikan stimulasi sosial, dan prilaku positif dapat dibentuk dengan menghindari pembatasan dan hukuman pada anak.

Pada Penelitian lain menjelaskan hubungan antara persepsi siswa tentang pola asuh orang tua dan regulasi diri dengan keterampilan sosial sangat berpengaruh positif dalam memperbaiki dan meningkatkan keterampilan sosial anak (Nuperawati, Yufiarti, \& Sumantri, 2018). Kemudian terdapat juga hubungan orientasi budaya terhadap peningkatan kompetensi sosial yang dimiliki anak (Ren \& Wyver, 2016). Selanjutnya penelitian Benavides-nieto, Romero-lópez, Quesada-conde, \& Corredor, (2017) menjelaskan bahwa terdapat hubungan positif antara keterampilan sosial dan fungsi eksekutif anak, jika fungsi eksekutif anak dapat dioptimalkan dengan baik maka keterampilan sosial anak dapat meningkat.Dari beberapa hasil penelitian di atas dapat diketahui bahwa keterlibatan orang tua dan guru dapat mempengaruhi keterampilan sosial anak. Berdasarkan hasil obsevasi dilapangan bahwa keterampilan sosial anak masih rendah, hal ini telihat dari adanya sikap anak yang tidak memperhatikan arahan guru, anak belum bisa mengalah dan menuggu giliran saat main, ada beberapa anak cendrung bermain sendiri dan tidak mau bekerja sama melakukan kegiatan dengan teman. Salah Satu penyebab rendahnya keterampilan sosial anak adalah karena pembagian tugas masih bersifat indiviDual, metode pembelajaran yang sering digunakan juga metode ceramah, pembelajaran juga berpusat pada kegiatan yang mengarah pada akademik, berupa lembar kerja dan buku, sehingga pembelajaran terasa tidak menyenangkan bagi anak.

Dari permasalahan tersebut maka dibutuhkan kegiatan untuk menstimulasi keterampilan sosial anak. Salah Satu alternatif tindakan yang dapat diberikan adalah kegiatan tari saman. Karena tari saman memiliki daya tarik dan menyenangkan bagi anak.Gerakkannya dinamis, dan mudah dilakukan. Gerakan tari saman mliputi gerakan tangan, badan, kepala dan dilakukan sambil duduk bersimpuh serta dimainkan secara bersama-sama.Berdasarkan penelitian terdahulu yang sudah dilakukan bahwa seni tari 
DOI: $10.31004 /$ obsesi.v4i1.339

dapat meningkatkan beberapa aspek perkembangan anak usia dini, diantaranya Tari tradisional yang menggunakan metode kerja tim dalam pembelajaran dapat meningkatkan keterampilan sosial anak di sekolah dasar (Masadis, Filippou, Derri, Mavridis, \& Rokka, 2019). Kemudian menurut Yazıcı dalam penelitianyaThe Impact of Art Education Program on the Social Skills of Preschool Children, bahwa program pendidikan seni dapat meningkatkan keterampilan sosial anak prasekolah (Yazıc1, 2017). Salah Satu aspek seni yang dimaksud adalah seni tari.Selanjutnya keterampilan sosial juga dapat ditingkatkan melalui tari kreatif (Masturah, Myrnawati, Hartati, \& Yetti, 2018), dan melalui tari Jaranan ( Syarif H., 2015).

Seni tari tidak hanya dapat meningkatkan keterampilan sosial anak namun, Pembelajaran Tari Pendidikan dapat Meningkatkan Kecerdasan Kinestetik Anak Usia Dini Melalui Metode Pembelajaran Aktif (Yetti \& Juniasih, 2016). Melalui tari pendidikan berbasis cerita juga dapat meningkatkan kreativitas gerak anak (Juniasih, 2015) Selanjutnya pengalaman gerakan menari dengan model pusat belajar siswa merupakan landasan penting dalam mengembangkan kecerdasan emosional anak sejak usia dini (Yetti, 2012), kemudian melalui pembelajaran gerak dasar tari minang dapat meningkatkan kecerdasan kinestetik anak (Restu, 2015).

Selanjutnya berkaitan dengan hasil penelitian terdahulu tentang tari saman yang sudah dilakukan bahwa kecerdasan emosi siswa kelas dasar dapat ditingkatkan melalui pendidikan Jasmani dan harmoni yang menjadikan Tari saman sebagai materi dalam pendidikan jasmani (Rustiana, 2013), melalui tari saman juga dapat mengembangkan pembelajaran siswa tentang unsur-unsur matimatika frieze group yang terdapat dalam tari saman (Oktavianto, Ratnasari, \& Puspitasari, 2010).Kemudian tari nusantara (Tari Saman) dapat membangun pendidikan multikultural, (Sustiawati, 2011).Tari saman berasal dari Gayo Lues, hal ini dapat dilihat dari hasil penelitian HeniwatySaman Dance Of The Aceh People: Identity Actualization, yaitu menganalisis tari Saman masyarakat Aceh yang berfokus pada analisis fungsi Saman yang menjadi identitas orang Gayo. Identitas dan aktualisasi Saman sesuai dengan agama dan adat istiadat orang Gayo yang terdiri dari beberapa aspek tarian rakyat Aceh, seperti: kehidupan sosial-agama, filsafat, simbol, norma dan etika (Heniwaty, 2018). Dari hasil Analisis, tari saman memiliki beberapa nilai yang menjadikannya sebagai identitas masyarakat Aceh di masa sekarang dan masa depan. Dari beberapa penelitian tersebut belum ada penelitian yang menerapkan kegiatan tari saman upaya meningkatkan keterampilan sosial anak. Dapat disimpulkan juga pembelajaran tari tidak hanya mengembangkan dalam bidang ranah psikomotorik semata namun dapat mengembangkan kemampuan dalam bidang afektif dan kognitif anak.

Keterampilan yang dimaksud adalah sosial anak adalah Menurut Patrick Social skills are the capabilities that weare expected to use to interact with others in our society dapat di artikan bahwa keterampilan sosial adalah kemampuan yang di harapkan pada setiap individu yang digunakan untuk berinteraksi dengan orang lain dalam masyarakat (Nancy j. Patrick, 2008). Pendapat lain keterampilan sosial merupakan bentuk perilaku hubungan individu dengan orang lain yang sudah terbentuk melalui berbagai pengalaman intraksi sosial (Hapidin, 2015). Keterampilan sosial mempunyai pengaruh besar terhadap kesuksesan seseorang karena dapat mengembangkan mental secara sehat dalam beradaptasi dan keterampilan dalam bidang akademik, sejalan dengan pendapat Kızbes Meral Kılıç, bahwa keterampilan sosial adalah suatu periode positif untuk mengembangkan individu dalam hal kesehatan mental, adaptasi, dan keterampilan akademik untuk masa depan (Kizbes Meral Kilıc, 2017).Kemudian Menurut May keterampilan sosial adalah kombinasi kepribadian dan pengalaman anak yang terdiri dari mampu menghargai bagaimana perasaan orang lain (sering disebut empati), dan memiliki kesejahteraan orang lain di hati (sering disebut altruisme). Kemudian Keterampilan sosial juga memiliki kaitan yang erat dengan intraksi dan sikap (May,2011). Selanjutnya keterampilan sosial adalah kemampuan untuk melakukan inisiasi dan respon yang benar pada intraksi sosial (Ren \& Wyver, 2016). Segrin dalam (Koç 
\& Turan, 2018) juga menyatakan bahwa keterampilan sosial adalah kompetensi untuk membangun hubungan yang tepat dan efektif dengan orang lain.

Dari beberapa pendapat di atas dapat simpulkan bahwa keterampilan sosial adalah bentuk prilaku kemampuan seseorang dalam berintraksi dengan orang lain, sehingga memudahkan seseorang untuk beradaptasi dengan sesama baik individu maupun kelompok dalam hal bekerjasama, kontrol diri, berkomunikasi, dan berempati. Berdasarkan hasil penelitian relevan dan fakta masalah tari saman dapat dijadikan salah Satu alternatif untuk meningkatkan keterampilan sosial anak.

\section{METODOLOGI}

Penelitian ini dilakukan di SD Satu Rikit Gaib, Kabupaten Gayo Lues, Provinsi Aceh. Pada tahun ajaran 2018/2019. Terfokus pada kelas Dua SD yang berjumlah 11 siswa. Tujuan penelitian dilakukan untuk mengetahui upaya peningkatan keterampilan sosial anak melalui kegiatas tari saman. Metode penelitian yang digunakan adalah penelitian tindakan (Action Research), model kemmis dan Mc Taggart. Perencanaan penelitian tindakan ini menggunakan Dua siklus, siklus Isebanyak delapan kali pertemuan dan siklus II empat kali pertemuan. Perencanaan sebagai dasar untuk memecahkan masalah. Apabila siklus pertama belum tercapai maka dilanjutkan pada siklus keDua dan seterusnya sampai tercapai tujuan penelitian. Penelitian ini dilakukan bersama kolaborator yang akan memberikan tindakan dan peneliti sebagai obsever. Teknik analis data yang dilakukan dalam penelitian ini adalah Dua yaitu analisis data kuantitatif dan analisis data kualitatif.

\section{HASIL DAN PEMBAHASAN}

Hasil penelitian di sekolah SD 1 Rikit Gaib. Menunjukkan bahwa kegiatan tari saman dapat meningkatkan keterampilan sosial anak kelas 2 Sekolah Dasar, dengan keseluruhan skor terakhir sebesar $81 \%$. Hasil Analisis data pada penelitian ini bertujuan untuk melihat proses kegiatan tari saman dalam meningkatkan keterampilan sosial anak di sekolah SD Satu Rikit Gaib. Hasil penilaian autentik keterampilan sosial anak terhadap kegiatan tari saman pada pra siklus, siklus I dan siklus II yaitu dapat dilihat pada tabel dan grafik sebagai berikut:

Tabel 1

Data Pra Siklus, Siklus I, dan Siklus II Keterampilan sosial anak

\begin{tabular}{|c|c|c|c|c|}
\hline No. & $\begin{array}{c}\text { Nama } \\
\text { Resp }\end{array}$ & $\begin{array}{c}\% \\
\text { Pra } \\
\text { Siklus }\end{array}$ & $\begin{array}{c}\% \\
\text { Siklus } 1\end{array}$ & $\begin{array}{c}\% \\
\text { Siklus II }\end{array}$ \\
\hline 1 & $\mathrm{Fi}$ & $47 \%$ & 62,5 & 80,3 \\
\hline 2 & Ak & $45 \%$ & 62,5 & 80,5 \\
\hline 3 & Akm & $48 \%$ & 62 & 77,8 \\
\hline 4 & $\mathrm{Hu}$ & $48 \%$ & 69 & 85,5 \\
\hline 5 & Ih & $49 \%$ & 63,5 & 77 \\
\hline 6 & Il & $50 \%$ & 70,5 & 84,8 \\
\hline 7 & $\operatorname{Re}$ & $50 \%$ & 64 & 77 \\
\hline 8 & $\mathrm{Ri}$ & $46 \%$ & 63 & 78,3 \\
\hline 9 & Sa & $50 \%$ & 69,5 & 84,3 \\
\hline 10 & $Y u$ & $48 \%$ & 68 & 81 \\
\hline 11 & $\mathrm{Za}$ & $47 \%$ & 68 & 84,8 \\
\hline & $\begin{array}{c}\text { Rata- } \\
\text { rata }\end{array}$ & $48 \%$ & 65,7 & 81,0 \\
\hline
\end{tabular}


DOI: $10.31004 /$ obsesi.v4i1.339

Berdasarkan tabel di atas keterangan Kategori keberhasilan anak dapat dilihat sebagai berikut :

Tabel.2 Kategori Penilain

\begin{tabular}{cc}
\hline Skor & Kategori \\
\hline $81-96$ & SB (Sangat Baik) \\
$62-80$ & C (Cukup) \\
$43-61$ & B (Baik) \\
$24-42$ & K( Kurang) \\
\hline
\end{tabular}

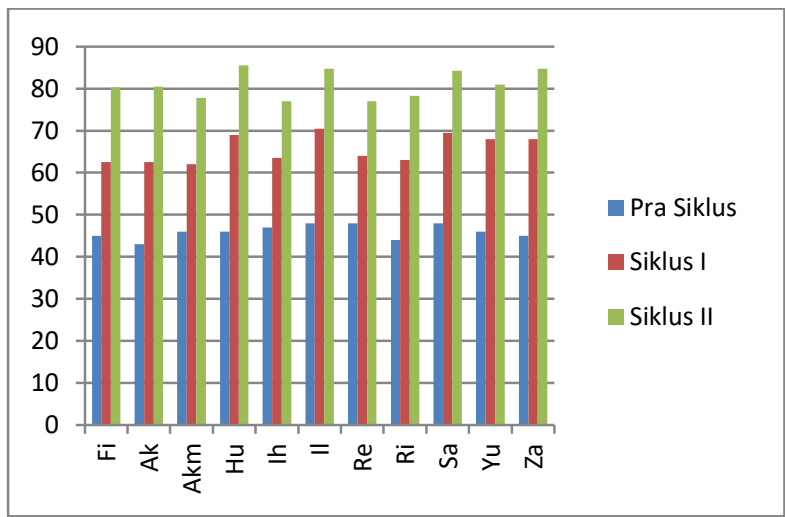

Grafik 1

Presentase Peningkatan Keterampilan Sosial melalui kegiatan Tari saman Prapenelitian, Siklus I dan Siklus II

Apabila dibandingkan keterampilan anak dalam kegiatan tari saman yang dilakukan pada setiap tahap tindakan yang diberikan, makadapat dilihat terjadinya peningkatan. Perbandingan antara kemampuan anak sebelum dan sesudah tindakan mengalami peningkatan, walaupun peningkatan yang terjadi tidak terlalu tinggi namun sudah melebihi indikator keberhasilan yang di tetapkan sebelum penelitian berlansung sebesar $47 \%$. Jadi penelitian ini dapat dikatakan berhasil karena anak sudah melebih indikator keberhasilan sebesar $75 \%$. Maka dari itu pembelajaran kegiatan tari saman mampu meningkatkan keterampilan sosial anak kelas Dua SD Negeri Satu Rikit Gaib.

\section{Pembahasan}

Proses kegiatan tari saman dapat meningkatkan keterampilan sosial anak kelas Dua SD Negeri Satu Rikit Gaib

Sebagaimana judul penelitian yang diteliti dalam penelitian ini, peneliti memilih kegiatan tari saman untuk meningkatkan keterampilan sosial anak. Proses pembelajaran pada anak usia dini hendaknya dilakukan dengan cara kegiatan dan melakukan kegiatan yang menyenangkan bagi anak, karena saat kegiatan anak mendapat pengetahuan. Pada saat kegiatan anak-anak juga belajar melalui intraksi dan pengalaman-pengalaman nyata yang dialami anak dalam kehidupan sehari-hari. Melalui pembelajaran nyata dan eksplorasi terhadap lingkungan, anak anak dapat belajar membangun pengetahuannya.

Salah Satu kegiatan seni yang menyenangkan dan sangat sering dilakukan anak-anak adalah menari. Pembelajaran tari saman dapat membantu anak untuk meningkatkan keterampilan sosial anak yang akan bermanfaat pada dirinya sendiri dan juga orang lain. 
Pemberian tindakan tari saman merupakan salah Satu bentuk kegiatan yang menyenangkan bagi anak dan dapat menstimulasi keterampilan sosial anak secara optimal. Kegiatan tari saman tidak hanya mengembangkan keterampilan sosial anak namun dapat mengembangkan aspek perkembangan lainnya. Seperti aspek kognitif, aspek motorik dan juga bahasa anak. Sehingga hasil yang ingin dicapai dalam keterampilan sosial dapat meningkat secara signifikan. Menurut Geršak, (2012) dalam penelitiannya tentang creative movement an opportunity for affective education bahwa terdapat hubungan antara menari dan hubungan afektif dalam hal kesejahteraan, kerjasama, komunikasi, empati, pemecahan masalah kelompok dan pengurangan prilaku agresif. Dengan demikian kegiatan tari dapat dijadikan sebagai metode holistic di sekolah dasar awal sebagai salah Satu elemen penting dalam dunia pendidikan. Pelaksanaaan kegiatan tari saman merupakan salah Satu kegiatan seni yang dapat di implementasikan kepada anak sekolah dasar terutama kelas awal dengan tujuan untuk membantu meningkatkan keterampilan sosial anak.

Proses keterampilan sosial yang terjadi ketika anak diberikan kegiatan tari saman adalah pada awalnya guru melakukan diskusi bersama tentang tari saman, guru menstimulasi anak untuk berani menceritakan pengalamanya mengenai tari saman yang pernah dilihat anak maupun yang pernah ikut menjadi anggota tari saman sebelumnya, anak bekerja sama dengan temannya saling membantu dalam menyatukan gerakan, kemudian pada saat proses latihan anak juga mengendalikan dirinya untuk sabar dalam mengutarakan pendapat dan belajar menghargai pendapat temannya. berdasarkan hasil penelitian terdahulu tentang kegitan menari. Tari tradisional yang menggunakan metode kerja tim dalam pembelajaran dapat meningkatkan keterampilan sosial anak disekolah dasar (Masadis et al., 2019).

Menurut Walter \& Sat, (2013) bahwa terdapat dampak menari terhadap pengendalian diri, regulasi diri, dan percaya diri anak usia dini di ruangan terbuka dengan menari lingkaran. Dari temuan tersebut menunjukkan adanya keterkaitan antara menari dengan pengendalian diri, regulasi diri dan percaya diri anak dimana hal tersebut merupakan salah Satu aspek dari keterampilan sosial.

Adapun langkah-langkah pembelajaran kegiatan tari saman dimulai dengan kegiatan pembuka, kegiatan pembuka ini berjalan dengan baik dan dapat terlihat peningkatan keterampiln sosial anak. Kegiatan pembuka yaitu menanyakan kabar, memberikan semangat dan melakukan diskusi tentang tari saman dan mengingat aturan yang telah dibuat secara bersama. Dikegiatan awal ini anak sudah mulai terlihat keterampilan sosial yang dimilikinya dengan cara anak berkomunikasi, bekerjasama, mengontrol dirinya dan mampu menghargai apa yang telah disampaikan temanya maupun orang dewasa.

Kegiatan inti, kegiatan inti dalam kegiatan tari saman berjalan dengan baik, pelaksanaan atau pengajaran setiap gerakan tari saman dilakukan secara bertahap kepada anak dengan tujuan agar anak dapat meniru setiap gerakannya dengan baik, dimulai dengan gerakan yang terdapat dalam tari saman yaitu Rehum, anak lagu, surang saring, gerpuk, anak lagu, lagu dan gerpuk. Awalnya ada beberapa anak yang terlihat kurang semangat karena belum pernah memiliki pengalaman menari, namun sejalan proses latihan tari saman yang diberikan anak memiliki rasa ingin tau dan semakin semangat mencoba meniru gerakan tari saman. Saat latihan guru menanyakan pada anak tentang perasaan mereka sedang menari, anak sangat antusias dan senang menari karena tari sama merupakan budaya yang berasal dari tempat tinggalnya dan anak terlihat aktif saat latihan tari saman.

Kegiatan penutup, saat kegiatan penutup keterampilan sosial anak terlihat setelah latihan kegiatan tari saman. Peningkatan keterampilan sosial anak dapat dilihat pada saat anak menjawab pertanyaan yang diberikan, saling mengingatkan temannya saat melakukan kesalahan dan saat anak-anak kegiatan dengan teman sejawatnya.

Keterampilan sosial anak berpengaruh dengan cara yang positif hal ini didukung dengan antusias anak terhadap kegiatan tari saman, dan saat latihan berlansung anak-anak 
DOI: $10.31004 /$ obsesi.v4i1.339

sangat antusias mengikutinya. Aspek -aspek keterampilan sosial yaitu kerjasama, kontrol diri, komunikasi dan empati.

\section{Hasil peningkatan keterampilan sosial anak kelas Dua SD Negeri Satu Rikit Gaib melalui kegiatan tari saman.}

Penelitian tindakan ini fokus pada peningkatan keterampilan sosial anak yang terdiri dari beberapa aspek diantaranya aspek kerjasama, kontrol diri, komunikasi, dan empati. Hasil tindakan kegiatan tari saman dalam meningkatkan keterampilan sosial antara lain adalah :

Aspek kerjasama merupakan salah Satu aspek dari keterampilan sosial. karena setiap individu sebagai makhluk sosial yang selalu berintraksi secara terus menerus, membutuhkan kehadiran dan bantuan orang lain. aspek kerjasama meningkat hal ini dapat dilihat katika proses latihan menari dan setelah kegiatan tari saman. Pada saat latihan tari anak harus saling bersinergi dan guru terus memberikan setimulasi agar anak mampu bekerjasama dalam menyatukan ide, gerakan, dan lantunan syair. Temuan ini semakin terlihat ketika di siklus II. Anak terlihat mampu berkerjasama.

Kontrol diri merupakan aspek keterampilan sosial karena setiap individu memiliki keterampilan sosial yang baik adalah anak yang mampu mengontrol dirinya dengan baik. Hal ini dapat dilihat saat anak mengontrol emosinya saat berintraksi dengan orang lain dan anak mampu menaati peraturan. Kontrol diri anak kelas Dua SD Negeri Satu Rikit Gaib terjadi ketika anak sabar menghadapi ketika temanya melakukan kesalahan berulang ulang kali dalam gerakan tari, anak menaati peratutan yang telah dibuat bersama.

Komunikasi merupakan salah Satu aspek dari keterampilan sosial. komunikasi anak dapat terlihat meningkat ketika anak menyatakan pengalamanya saat melakukan diskusi bersama dengan guru, anak dapat menggunakan etika dalam berkomunikasi dan anak mampu berinteraksi antara Satu sama lainya. adapun diskusi yang dilakukan adalah tentang bagaimana pengalaman anak tentang belajar tari saman, gerakan apa saja yang telah diajarkan, kemudian apakah anak sudah menhafal syair yang dilantunkan saat menari, kemudian guru juga menyampaikan pada anak, saat penampilan tari saman anak akan memakai baju adat tari saman yang berasal dari Gayo Lues.

Selanjutnya empati juga merupakan aspek keterampilan sosial.Empati merupakan sebuah tindakan yang baik. Sikap empati sangat diperlukan supaya seseorang bisa bertindak tanpa menyakiti orang lain. sikap empati anak muncul saat anak mau menolong teman yang kesulitan, berbagi makanan dan saat menghargai orang lain.

Berdasarkan dari hasil analisis data diperoleh data bahwa pada siklus I sebesar $65.7 \%$ dan siklus II sebesar $81 \%$. Hasil tersebut diperoleh berdasarkan hasil penilain observasi, oleh karena itu peneliti dan kolaborator merasa hasil yang didapat cukup dan memutuskan untuk menghentikan penelitian pada siklus II pertemuan ke Empat. Hasil tersebut dapat menunjukkan kesesuaian dengan hipotesis tindakan yaitu dengan presentase minimum sebesar $75 \%$ maka hipotesis diterima. Dengan demikian hipotesis tindakan yang menyatakan bahwa melalui kegiatan tari saman dapat meningkatkan keterampilan sosial anak kelas Dua SD Negeri Satu Rikit Gaib diterima. Prolehan presentase setiap anak pada setiap siklus berbeda-beda. Hal ini dapat dipengaruhi oleh faktor internal dan eksternal.

\section{KESIMPULAN}

Keterampilan sosial anak mengalami peningkatan setelah melakukan kegiatan tari saman. Hal ini terlihat dari hasil lembar penilain indikator keterampilan sosial yang terdiri dari anak empat aspek diantaranya anak mampu bekerjasama, kontrol diri, berkomunikasi dan bersikap empati. Kegiatan tari saman dapat meningkatkan keterampilan sosial anak kelas Dua SD Negeri Satu Rikit Gaib, kabupaten Gayo Lues Aceh. Peningkatan keterampilan sosial anak terjadi ketika anak berkomunikasi dengan temannya kemudian saat melakukan diskusi bersama mengenai tari saman, anak bekerja sama dengan temannya, anak 
mengontrol emosinya saat temannya melakukan kesalahan, dan anak juga melakukan saling membatu teman yang kesulitan.

\section{UCAPAN TERIMA KASIH}

Hamdan wa syukran lillah, Puji Syukur Kehadiran Allah SWT dengan Rahmat dan RahimNya telah melimpahkan penulis kekuatan, kesehatan, dan kemudahan dalam menyelesaikan tesis ini untuk memperoleh gelar master. Keberhasilan dalam menghadapi berbagai tantangan ketika menyusun dan menyelesaikan tulisan ini, tentu tidak lepas dari bantuan, arahan, motivasi, dan doa dari berbagai pihak. Oleh karena itu penuls ingin menyampaikan hiasan ribuan terimaksih kepada semua pihak yang secara lansung maupun tidak lansung telah memberikan kontribusi dalam penyelesaian tesis ini.

\section{DAFTAR PUSTAKA}

Benavides-Nieto, A., Romero-López, M., Quesada-Conde, A. B., \& Corredor, G. A. (2017). Basic Executive Functions in Early Childhood Education and their Relationship with Social Competence. Procedia - Social and Behavioral Sciences, 237(June 2016), 471-478. https:// doi.org/10.1016/j.sbspro.2017.02.092

Connor, A. M. O., \& Angela D. Evans. (2019). Journal of Experimental Child The role of theory of mind and social skills in predicting children' s cheating. Journal of Experimental Child Psychology, 337-347. https:// doi.org/10.1016/j.jecp.2018.11.018

Geršak, V. (2012). Creative movement - An opportunity for affective education. Taipei National University of the Arts, 1-10.

hannah pickard, Happe, F., \& Mandy, W. (2018). Navigating the social world : The role of social competence, peer victimisation and friendship quality in the development of social anxiety in childhood. Journal of Anxiety Disorders, 60(March), 1-10. https:// doi.org/10.1016/j.janxdis.2018.09.002

Hapidin. (2015). Asesmen dan Evaluasi Pendidikan Anak Usia Dini (Awaluddin Tjalla, Ed.). LPP Press Unerversitas Negeri Jakarta.

Heniwaty, Y. (2018). Saman Dance of The Aceh People: Identity and Actualization. Journal of Community Research and Service, 2(1), 184. https://doi.org/10.24114/jcrs.v2i1.10374

Juniasih, I. (2015). Peningkatan Kreativitas Gerak melalui Kegiatan Tari Pendikan Berbasis Cerita ( TARITA ). Pendidikan Usia Dini, 9(2), 319.

Kızbes Meral Kılıc. (2017). The Effect of Social Skills Training on Social Skills in Early Childhood, the Relationship between Social Skills and Temperament. Education and Science, 42(191), 185-204. https:/ / doi.org/10.15390/EB.2017.7162

Koç, K., \& Turan, M. B. (2018). The Impact of Cultural Intelligence on Social Skills among University Students. Journal of Education and Learning, 7(6), 241-249. https:// doi.org/10.5539/jel.v7n6p241

M. Arif Syarif H. (2015). Peningkatan Keterampilan Sosial melalui Tarian Jaranan Berkelompok. Universitas Negeri Jakarta.

Masadis, G., Filippou, F., Derri, V., Mavridis, G., \& Rokka, S. (2019). Traditional Dances as a Means of Teaching Social Skills to Elementary School Students. International Journal of Instruction, 12(1), 511-520. https:/ / doi.org/10.29333/iji.2019.12133a

Maturah, S. N., Myrnawati, Hartati, S., \& Yetti, E. (2018). The Improvement of Social Skills By Playing Creative Dance). (20).

Nancy j. Patrick. (2008). Social Skills for Teenagers and Adults. USA: Jessica Kingley Publishers London and Philadelphia.

Nuperawati, Yufiarti, \& Syarief Sumantri. (2018). Hubungan Antara Persepsi Siswa tentang Pola Asuh Orang Tua dan Regulasi Diri dengan Keterampilan Sosial Trika. Yaa Bunayya : Jurnal Pendidikan Anak Usia Dini, II No.1(Issn : 2580 -4197), 27-36.

Oktavianto, R. G., Raden Rara Lucia Hesti Ratnasari, \& Agty Devina Puspitasari. (2010). 
DOI: $\underline{10.31004 / \text { obsesi.v4i1.339 }}$

Frieze group dalam tari saman. 72-77.

Pamela May. (2011). Child Development In Practice. London \& New york: Routledge.

Ren, Y., \& Wyver, S. (2016). Social competence, cultural orientations and gender differences : a study of Mandarin - English bilingual preschoolers. Internasional Journal of Early Years Education, 9760(April). https://doi.org/10.1080/09669760.2016.1138282

Restu, Y. (2015). Pembelajaran Gerak Dasar Tari Minang Mahasiswa Pascasarjana Universitas Negeri Jakarta suatu kurang sehingga kecerdasan khususnya seni tari . Jurnal Pendidikan Usia Dini, 9 Edisi 2.

Rustiana, E. R. (2013). Upaya Peningkatan Kecerdasan Emosi Siswa Sekolah Dasar melalui Pendidikan Jasmani Harmoni. Cakrawala Pendidikan, (2006), 139-149.

Sustiawati, ni luh. (2011). Kontribusi Seni Tari Nusantara dalam Membangun Pendidikan Multikultur The Contribution of Archipelago Dance in Building the Multicultural Education. 26, 126-134.

Takahashi, Y., Okada, K., Hoshino, T., \& Anme, T. (2015). Developmental Trajectories of Social Skills during Early Childhood and Links to Parenting Practices in a Japanese Sample. Polos One, 1-14. https://doi.org/10.1371/journal.pone.0135357

Walter, O., \& Sat, E. (2013). Peningkatan Kreativitas Gerak melalui Kegiatan Tari Pendikan Berbasis Cerita ( Tarita ). 6(4), 77-97. https:// doi.org/0.24114/jcrs.v2i1.10374

Yazic1, E. (2017). The Impact of Art Education Program on the Social Skills of Preschool. Journal of Education and Training Studies, 5(5), 17-26. https://doi.org/10.11114/jets.v5i5.2231

Yetti, E. (2012). Pengaruh Model Pembelajaran dan Kemampuan Gerak Tari Terhadap Kecerdasan Emosional Anak Usia Dini. Jurnal Seni Dan Budaya Panggung, 22.No.2, 213-224. https://doi.org/10.26742/panggung.v22i2.63

Yetti, E., \& Juniasih, I. (2016). Implementasi Model Pembelajaran Tari Pembelajaran Aktif ( Pengembangan Model di Taman Kanak-Kanak Labschool Jakarta pada Program Studi Pendidikan Sendratasik, Fakultas Bahasa dan Seni Universitas Fakultas Ilmu Pendidikan, Universitas Negeri Jakarta. Pendidikan Anak Usia Dini, 10 Edisi 2(9). ttps://doi.org/10.21009/JPUD.102.11 